\title{
Apparent Comparative Advantage and Development Space in Women's Apparel Trade
}

\author{
Xin Zhao \\ Professor in Marketing, School of Business, University of Redlands \\ 1200 E. Colton Ave., Redlands, CA, 92373, USA
}

Tel: $909-748-8778$

Received: April 7, 2020 Accepted: April 28, 2020 Published: May 27, 2020

doi:10.5296/ber.v10i2.16799 URL: https://doi.org/10.5296/ber.v10i2.16799

\begin{abstract}
This study investigates the apparent comparative advantage of the world's top five women's apparel exporters in order to anticipate the development of future international women's apparel markets using Vollrath's Relative Trade Advantage (RTA) Index and market share analysis for both aggregate and disaggregate trade data from the UN Statistics Database for the years 1993-2007. Findings show the complexity of the comparative advantage concept and indicate that appearances can be deceiving. Outstanding performance for exporters based on RTA values at the aggregate level does not necessarily mean outstanding performance at the subcategory level. Furthermore, market share analysis shows that new players are making a strong showing in the women's apparel trade. Niche opportunities are revealed for the current export leaders, as well as up-and-coming apparel exporters. The results suggest that Vollrath's RTA Index, heretofore little used in the apparel trade area, offers a useful additional perspective on comparative advantage and should be considered for use in future apparel trade studies.
\end{abstract}

Keywords: Vallrath's Relative Trade Advantage (RTA), Comparative advantage, Apparel, Women's apparel

Empirical measures of aggregate comparative advantage can identify the overall direction and thrust which a country's investment and trade should take in order to exploit international differences in product and factor supply and demand.

Thomas L. Vollrath

\section{Introduction}

The Executive Forum 2002 concluded that in an increasingly liberalized world trade 
environment, strategies must create, improve, and/or maintain advantage in the marketplace (Kirchbach, 2003). Nowhere is this truer than for the apparel trade, "the quintessential global industry in which the world's largest retailers, branded marketers, and manufacturers without factories are the dominant players" (Gereffi 1999; Tokatli \& Kizilgun, 2004, p. 223). Often the apparel trade competes on leading-edge research, design, sales, marketing, and brand development, rather than on the volume, scale, resource, and technological issues that spell success in other industries (Gereffi, 1999). Apparel's complex, low capital-intensive trade environment means that countries must vie harder to establish successful trade niches built upon differing industrial, environmental, and national conditions (Kaplinsky, 2000; Tokatli \& Kizilgun, 2004; Jin, 2004). Both governments and individual investors want insight into the future of this complex trade area and the opportunities that may exist for apparel exporters.

Investigating the future opportunities for apparel exporters, however, presents its challenges. First, it entails understanding that comparative advantage - the concept that countries and firms seek to produce goods in which they have relative resource advantages over other countries and firms - shifts as resources ebb and flow and as "key" resources are redefined by technology and other market factors. Second, it involves managing recalcitrant data from both extant research findings and the available trade databases. For example, the value of past research findings has often been limited due to a focus on aggregate level data analysis. Furthermore, the inconsistent reporting structure for apparel trade data at the aggregate and disaggregate levels complicates analysis and interpretation. A final challenge includes the limited number of approaches by which comparative advantage has been investigated.

In response to these challenges, this study seeks to understand historical apparel export patterns to identify future opportunities better through the analysis of the comparative advantage of the top apparel exporters and what that advantage might mean for future development of international apparel markets for them, as well as other countries. This study focuses on the women's apparel trade because of its position as the largest sector in the apparel market, its impact on the world's largest importers, the United States and the European Union, and its unique role as a driver of fashion and branding (Jones, 2003). Specifically, to address the broader research question the study seeks to achieve the following objectives: (1) to assess comparative advantage, an under-researched area in women's apparel trade; (2) to explore both aggregate (apparel total and women's apparel total) and disaggregate (women's apparel subcategory) apparel trade data using the UN Statistics Database; and (3) to provide a fresh look at comparative advantage by applying Vollrath's Relative Trade Advantage Index, a comparative advantage index heretofore used primarily in agricultural trade studies.

To frame the study, this article first presents the theoretical frame used, a brief review of the top five women's apparel exporters and the data analysis. The article concludes with a discussion of the implications of the study results.

\section{The Theoretical Framework}

A fundamental economic question in international trade is why countries trade what they trade, especially as economies have become more complex and global—a question of 
comparative and/or competitive advantage. Doryan (1993) points out a critical difference between these two concepts, defining comparative advantage as what resources a country has and competitive advantage as the ability of a country to add value to available resources. Certainly, the fight for world market share has made it necessary for individual nations to leverage comparative advantages to become or remain competitive, including leveraging costs, technology, knowledge, and government policies. Competitiveness is sometimes expressed as a combination of comparative advantage and existing market distortions (Tefertiller and Ward, 1995).

The theory of comparative advantage, which has theoretical roots dating back over two centuries, seeks to explain why exporters focus on particular products and industries. Adam Smith (1776) first suggested in his Theory of Absolute Advantage that different nations can produce certain goods more efficiently than others because of absolute cost advantages, leading nations to import goods where absolute cost disadvantages exist and to export goods where absolute cost advantages exist. David Ricardo (1817) challenged Smith's theory, showing that without absolute advantages, nations could trade as long as production cost differences existed. Using the labor theory of value concept, Ricardo (1817) developed the Theory of Comparative Advantage, suggesting that nations import goods where there is relatively less labor cost advantage and export goods where there is relatively more labor cost advantage relative to other nations. Ricardo's simple numerical example crystallized economists' understanding and changed the scope of the debate over the determinants and gains from trade (Maneschi, 1998). Vilfredo Pareto (Maneschi, 1998) further developed the comparative advantage concept by including opportunity costs. This increased the precision of analysis, clarified the concept of comparative advantage and specialization in terms of the optimal allocation of resources, and expanded the analysis of comparative advantage to provide better understanding of international trade. Pareto (Maneschi, 1998) also pointed out that the concept was applicable to the gains from specialization at any level of data aggregation.

Over time, three main streams of research on comparative advantage have emerged: (1) government policies that distort trade and keep it from reflecting the pattern of comparative advantage (Deardorff, 1979); (2) applications and implications of different indices (Balassa, 1965; Yang, 1999); and (3) comparisons between varieties of comparative advantage indices (Ballance, Forstner, \& Murray, 1987; Webster, 1990). Across these streams, two views of comparative advantage have also developed. Some researchers have been passionate about the comparative advantage concept and the value of its application. Others, such as Maneschi (1998), suggest that the Law of Comparative Advantage holds as a law of tendencies, but is ungrounded with respect to trade in any particular good-a debate that remains part of the current economic research area. French (2017) shows that empirical applications favor the first view. This study also positions itself philosophically with the first view, which assumes comparative advantage can be measured or estimated and used to help explain trade patterns, i.e., a "revealed" comparative advantage estimated from trade data. In the apparel area, studies have focused primarily on textile and apparel trade liberalization, trade-related labor adjustments, trade-related technology changes, and business facilitation (Walkenhorst, 2003), 
suggesting that developing countries should be able to maintain comparative advantage in textiles and apparel and to gain welfare upon the elimination of textile and apparel quotas under the Multi-Fiber Agreement (MFA), which took place on January 1, 2005. Although comparative advantage has been mentioned in some apparel studies, such as Yang (1999), it is a topic that has received relatively little attention in the apparel trade area.

\section{Vollrath's Three Measures of Comparative Advantage}

Although comparative advantage is critical to understanding success in international trade, measuring comparative advantage is theoretically complex and practically challenging because of data issues. Balassa (1965) introduced the first widely recognized index, the Revealed Comparative Advantage Index, designed to assess comparative advantage in international trade. This index uses export data only. Inspired by Balassa's (1965) work and seeking to improve comparative advantage analysis, Vollrath in 1987 introduced three new measures of comparative advantage, the Relative Export Advantage (RXA) Index, the Relative Trade Advantage (RTA) Index, and the Revealed Competitiveness (RC) Index. Vollrath first used the Relative Trade Advantage (RTA) Index in his 1992 study of US agricultural trade with Bangladesh to avoid the RC Index distortions caused by small import/export values.

After reviewing 10 comparative advantage indices that have been used in the literature, Vollrath (1991) concluded that his Revealed Competitiveness (RC) Index and the Relative Trade Advantage Index are the preferable measures of comparative advantage, because these indices are theoretically more compatible with the concept of comparative advantage. The benefits of using Vollrath's (1987) RTA Index include: (1) extending analysis to incorporate export and import data, capturing the reality of the two-way transactions that actually take place in trade; (2) reducing sensitivity to extremely small values of trade data by avoiding the use of the logarithm format (used by the RC Index); and (3) the elimination of double counting of both commodity and country. The RTA is found by calculating a good's importance to a country's total exports relative to that good's importance to the rest of the world's exports. The same relationships are calculated for the good's imports. The difference between the two is the RTA.

Although Vollrath has applied his indices to his own research on agricultural trade, Havrila \& Gunawardana's (2003) investigation of Australian aggregate commodity groups of textiles and clothing is the only research that has directly utilized Vollrath's indices other than Vollrath's own studies.

\section{The World's Top Five Apparel Exporters}

As our base year of analysis, we chose 2003, the year when the Agreement on Textile and Clothing, ATC, was dissolved and free market forces became dominant in apparel. Between 1994 and 2003 total world apparel exports grew 42\%, resulting in the following five top apparel exporting entities based on dollar export value in 2003 - China $\left(1^{\text {st }}\right)$, Hong Kong $\left(2^{\text {nd }}\right)$, Italy $\left(3^{\text {rd }}\right)$, Turkey $\left(4^{\text {th }}\right)$, and Germany $\left(5^{\text {th }}\right)$ (available from unstats.un.org, 2005). These five trading entities accounted for almost $53 \%$ of global apparel trade. At this time, Germany and 
Italy were classified as developed nations (DN); Hong Kong as one of the newly industrialized economies (NIEs); and China and Turkey as developing nations (DGN). Hong Kong on July 1, 1997 changed from being a British crown colony to the first Special Administrative Region (SAR) of Mainland China. Because Hong Kong remains a separate entity from China for customs purposes due to entrepôt trade and value added (Feenstra, Hai, Woo, and Yao, 1999) and because re-exported Chinese goods are still recorded as Hong Kong exports, this study treats China and Hong Kong as separate trading entities (Feenstra, Hai, Woo, \& Yao, 1999). Supporting this decision, re-exports of Chinese apparel goods from 1994 to 2003 through Hong Kong have been estimated to be only between one and three percent (UN Statistics Database).

In considering the apparel export market, it would be expected that the top exporting nations would exhibit a significant comparative advantage, increasing their export shares and with increased specialization, consequently possibly even increase their comparative advantage positions. Given that comparative advantage is, in part, defined as having superior, relevant resources, it would also be expected that the world's top exporting nations would demonstrate leverage in one of the three types of resource advantage: labor, land and/or physical capital. For the apparel industry, labor has traditionally been a major component of production and therefore a major source of advantage. For example, labor costs in China have been much less than in more advanced economies, due to the country's oversupply of labor and low gross domestic product (GDP) per capita (Chun, 2003). This resource advantage forms one explanation for China's strong performance in the apparel trade in the recent past and its probable continued prosperity in the future.

\subsection{China}

China, the number one apparel producing and exporting nation in the world, produced over 7.6 billion items of clothing in 2003 (Chen \& Shih, 2004) and recorded a total of $\$ 52.2$ billion in apparel exports - almost twice that of its nearest competitor (available from unstats.un.org, 2005). The textile and apparel industries occupy important places in the Chinese economy (Chen \& Shih, 2004). The textile industry, the older and more mature of the two industries, has reached a higher level of development (Chen \& Shih, 2004). Because the apparel industry has been in place a shorter period of time, apparel manufacturers tend to be smaller in size and influence (Chen \& Shih, 2004). Since the economic reform of 1979, the Chinese government has given apparel companies considerable latitude with only $2 \%$ of Chinese clothing companies in 2002 owned or controlled by the state (Taylor, 2004). This has resulted in an explosion of economic activity, exemplified by the nearly 10,000 apparel firms operating in China in 2003. The vast majority of garment, shoe, and hat manufacturing companies, $81.77 \%$ of them, are concentrated in six regions of China, Guandong, Zhejiang, Jiangsu, Shanghai, Fujian, and Shandong (Chen \& Shih, 2004).

China's growth in the apparel industry has been built on low wages, intensive training programs through joint ventures, and positive government policies encouraging technology, investment, and skilled management (Chun, 2003). China's apparel industry has been furthered by the growth of regional industry clusters that have focused on particular market 
segments, offering high efficiency, low costs, and easy access that have attracted world import companies and foreign investment (Sonobe, Hu, \& Otsuka, 2002; Thompson, 2002). China experienced a 119\% growth in apparel exports between 1994 and 2003.

\subsection{Hong Kong}

In our reference year, Hong Kong was second in the world apparel export market with $\$ 23.2$ billion in exports in 2003 (available from unstats.un.org, 2005), has been called an economic miracle "fueled by the textile and apparel industries" (Jin, 2004, p.230). The apparel industry in Hong Kong began in the 1950s and 1960s with original equipment manufacturing firms. This transitioned into internationalized offshore sourcing and, eventually, in the 1970s and 1980s into triangle manufacturing (Jin, 2004). Triangle manufacturing transformed Hong Kong apparel firms into middlemen, as they subcontracted part or all of production orders to lower-wage locations such as Sri Lanka and Thailand. These firms built their success on a unique structure of triangle manufacturing and sourcing networks operated through extensive social ties. Hong Kong firms over the years have become pre-eminent in the logistical functions in China's apparel industry (Jin, 2004).

As is true for other Asian NIEs, Hong Kong has gained critical advantages for its apparel industry through integrated systems, brands, and business agility. Among Asian markets, Hong Kong apparel companies have been the most successful in breaking into branded merchandise (Jin, 2004). It has been noted that unlike trading entities newer to competing in the international apparel market, Hong Kong may be able to leverage its many years of foreign direct investment, outward processing, and facilitation of import/export matters in developing its future strategies. Hong Kong, like developed countries, has gone from providing simple labor to brand development to global sourcing for its domestic market. For these reasons, this geographically small trading entity has been characterized as "the showcase for what WTO membership and economic liberalization' could mean for China" (Taylor, 2004, p. 138). Hong Kong experienced an 8\% growth in apparel exports between 1994 and 2003.

\subsection{Italy}

Italy, the one apparel fashion leader among the top apparel exporters, ranked third in the world with \$16.2 billion in apparel exports in 2003 (available from unstats.un.org, 2005). While a strong contender in international apparel trade, the Italian textile and apparel industries also hold positions of leadership in Europe. For example, major European countries experienced a 40\% decrease in employment in the apparel industry between 1996 and 2002, while Italy experienced a 1\% increase in employment in this sector (Guercini, 2004).

The Italian apparel trade situation differs markedly from other European countries in the following ways: (1) the textile and apparel industries represent a much higher proportion of the manufacturing base and are responsible for one-third or more of the commercial trade surplus; (2) there is a dearth of both natural fibers and the raw materials needed for man-made fiber (MMF) production, making Italy highly sensitive to trends in international markets; (3) Italy's unique retail environment, with a strategic group of independent retailers 
strongly influences the apparel industry; and (4) the industrial organization through small and locally grouped industrial districts affects key functions such as distribution (Guercini, 2004). Porter (1990) has pointed out that the characteristics of Italian distribution have been a key factor in its apparel industry's long-held competitive position. Strategically, Italian apparel firms have tended to reduce product standardization and to pursue small niche markets (Guercini, 2004). Italy experienced a 29\% growth in apparel exports between 1994 and 2003.

\subsection{Turkey}

Turkey, a vibrant competitor ranked seventh in the world in apparel exports as of 2001 and fourth in 2003, with $\$ 10$ billion in apparel exports in 2003 (available from unstats.un.org, 2005), owes two major factors for its impressive growth: (1) government policy, including major industrial structural reform (Aricanli \& Rodrik, 1990; Kiray, 1990); and (2) the establishment of the Turkish Customs Union (CU) which opened up exports to the European Union (EU) (Neidik, 2004).

Although the CU between the European Union (EU) and Turkey was officially established in 1996, Turkish exports began to circulate freely in the EU much earlier, because EU member-states abolished tariff and non-tariff barriers against Turkey starting as early as 1973 (Mardas \& Moutos, 2002). Turkey's export strategy adopted in the 1990s was a huge turnaround from the 1960s and 1970s import substitution industrialization strategy which had produced a rapid but unsustainable spurt of economic growth (Ozcelik \& Taymaz, 2004). Instead, Turkey's more recent export strategy has sustained outstanding export performance in apparel despite stiff competition from other developing countries. Although Turkey has experienced growth in domestic outsourcing as a result of wage pressures, it has been through shifting garment production to lower wage areas within the country itself (Taplin \& Winterton, 2004). Overall, Turkey has experienced a 25\% cumulative increase in GDP since 2001 (OECD Observer, 2004) and a 117\% growth in apparel exports between 1994 and 2003.

\subsection{Germany}

Germany was number five in the world with $\$ 9.7$ billion in apparel exports in 2003 (available from unstats.un.org, 2005), in the early 1990s underwent significant changes in its apparel industry structure in response to import penetration, including changes in labor, product market conditions, and regulatory shifts (Rosen, 2003; Taplin \& Winterton, 2004). Germany's responses have been influenced by its highly regulated labor pool and a skilled workforce, as well as by a technological prowess that has been rendered null, given that technical modernization plays only a small role in garment production (Adler, 2004). Despite attempts, automation of apparel manufacture has been largely unsuccessful, preventing it from becoming a capital-intensive manufacturing environment (Adler, 2004). This combination of factors has resulted in increased overseas sourcing and outward processing, often with proximate low-wage countries such as Hungary (Taplin \& Winterton, 2004). Between 1980 and 2001, German clothing producers shrank from 3,210 companies to 613, while at the same time, the employee base shrank from 248,776 to 60,889 (Adler, 2004).

The German apparel industry has focused exclusively on cost management to deal with 


\section{Al Macrothink}

Business and Economic Research

ISSN 2162-4860

2020, Vol. 10, No. 2

import penetration, as opposed to pursuing a market-oriented strategy such as that adopted by the German textile industry (Adler, 2004). Consequently, many jobs have been lost, the apparel industry is shrinking, and the jobs remaining in Germany and most other European countries, except Italy and Turkey, tend to be in the value-added, design classifications, not production. Simple clothing needs, such as sportswear, accessories, shirts, and undergarments are being met by imports, while high quality products such as designer fashions, branded products, and casual wear market segments are still being served by German manufacturers (Adler, 2004). Between 1994 and 2003, German apparel exports held steady, fluctuating between approximately $\$ 7$ and $\$ 9$ billion annually, but demonstrating no sustained trend either up or down. Germany from 1994 to 2003 experienced 45\% growth in apparel exports.

\section{Methodology}

This study uses direct market share proportions and Vollrath's Relative Trade Advantage (RTA) Index to analyze and describe the relative performance of women's apparel trade exporters. Market share is calculated as individual exporter trade volume in product category or sub-categories in dollars divided by world total trade volume in that product category or sub-categories in dollars.

The index used to measure comparative advantage in this study is Vollrath's Relative Trade Advantage (RTA) Index and is calculated in the following manner:

$$
\begin{aligned}
& R X A_{\mathrm{ij}}=\left(X_{\mathrm{ij}} / X_{\mathrm{nj}}\right) /\left(X_{\mathrm{ir}} / X_{\mathrm{nr}}\right) \\
& R M A_{\mathrm{ij}}=\left(M_{\mathrm{ij}} / M_{\mathrm{nj}}\right) /\left(M_{\mathrm{ir}} / M_{\mathrm{nr}}\right) \\
& R T A_{\mathrm{ij}}=R X A_{\mathrm{ij}}-R M A_{\mathrm{ij}}
\end{aligned}
$$

where,

$R X A_{\mathrm{ij}} \quad=$ relative export advantage of country $j$ in commodity $i$

$R M A_{\mathrm{ij}} \quad=$ relative import advantage of country $j$ in commodity $i$

$R T A_{\mathrm{ij}}=$ relative trade advantage of country $j$ in commodity $i$

and,

$X=$ exports

$M=$ imports

$n=$ rest of the commodities

$r=$ rest of the world

The RXA and RMA Indices are used only for calculation of the RTA Index. According to Vollrath, positive values of the three indices indicate comparative advantage, while negative values indicate comparative disadvantage. It is important to note that these indices distinguish between a specific commodity/country and the rest of the commodities/countries. In this way, the indices avoid double counting a specific commodity or country in global trade. 


\section{Data Analysis and Results}

In order to achieve our research objectives, it was necessary to draw data from different SITC revisions. Data for total apparel (84) and total women's apparel (842 plus 844) were obtained from the UN Statistics Database based on SITC Revision III. Data for subcategories under women's apparel were taken from UN Statistics Database based on SITC Revision II. Data collection and organization differ between these two databases with Revision III providing a clearer delineation of product category by gender and Revision II providing a more detailed breakdown of the clothing categories by fiber content. There are seven 4-digit product groups of women's apparel selected for the purpose of this study, as well as twenty 5-digit subcategories.

\subsection{Global Total Apparel Trade: Market Share and RTA}

Recall that we used 2003 as our reference year due to the end of the ATC this year. Figure 1 presents the market share for the top five global apparel exporters in our reference year. According to the figure, the top five exporters by dollar volume included in this study accounted for almost 53 percent of the global apparel trade in 2003 and 59\% in 2017. Individually, China ( $\mathrm{CHN}$ ) had an obvious upward trend over the ten-year period investigated and reached 25 percent of world market share in 2003 and almost 40\% in 2017, which was more than twice the volume of any of its competitors in 2003, but almost four times in 2017, earning its reputation as an Asian giant. Germany (DEU) and Turkey (TUR) performed at a consistent level during this 25-year period with occasional fluctuations, each having around five percent of the world total market share, respectively. Hong Kong (HKG) experienced a consistent downward trend, only retaining about four percent of the world total market share for the apparel trade. Italy (ITA), on the other hand, also showed a consistent downward trend, but closed out the 25-year period with six percent of the world total market share for the apparel trade.

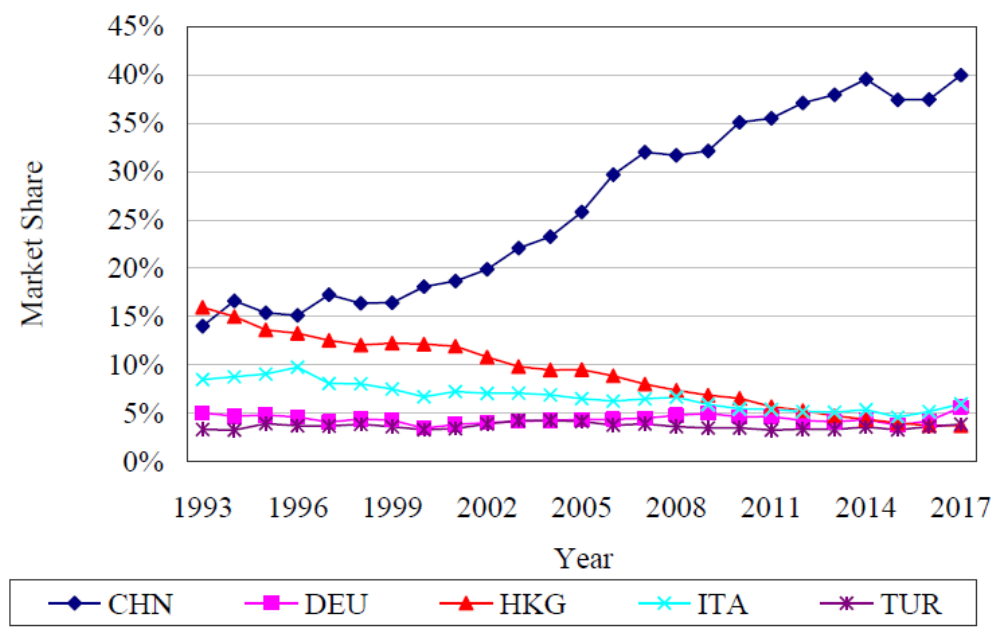

Figure 1. Market Share for the Top Five Exporters in Global Apparel Trade (SITC III 84): 1993-2017

Data Source: UN Statistics Database 


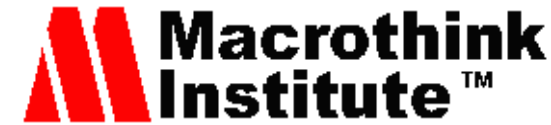

Business and Economic Research ISSN 2162-4860 2020, Vol. 10, No. 2

Figure 2 shows the results of Vollrath's Relative Trade Advantage (RTA) Index for the top five exporters in global apparel trade from 1993 through 2017. The RTA Index takes both export advantage and import advantage into account, making it a more accurate measure of the overall comparative advantage for a product/industry. The RTA Index is constructed to be the contrast of weight between a country's exports and imports in that specific product/industry compared to the rest of the world. According to Vollrath, positive values of the RTA Index mean a relative trade advantage, which indicates that exports weigh more heavily than imports in a given product/industry for that country compared to the rest of the world. Noticeably, except for Germany, the other four nations/regions to some degree had a descending trend in the RTA Index over the years reviewed, indicating a loss in trade advantage. Most notably even China, despite its strong increase in market share, saw its RTA index decline due to its even stronger export growth in other sectors. While Germany trended positively during this 25 -year period, it still remained within the negative range of values on the RTA Index, indicating what might be called a decreased disadvantage in global apparel trade.

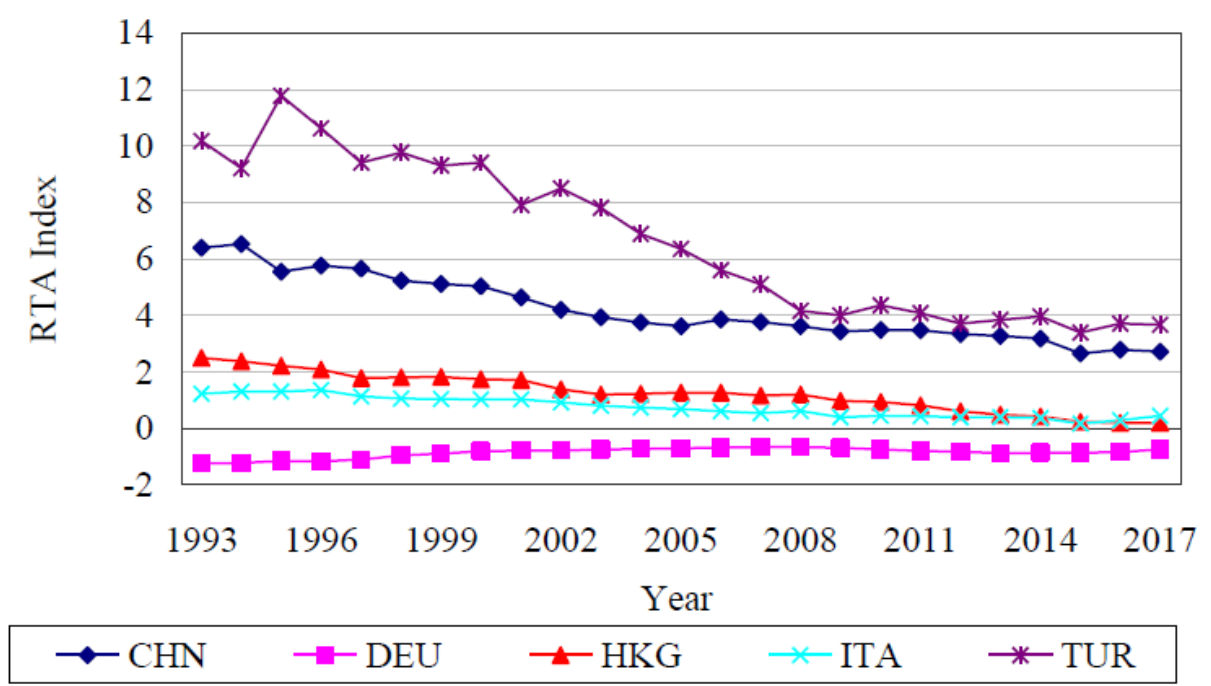

Figure 2. Vollrath's RTA Index Results for the Top Five Exporters in Global Apparel Trade (SITC III 84): 1993-2017

Data Source: UN Statistics Database

\subsection{Global Women's Apparel Trade: Market Share and RTA}

A comparison of Figure 1 and Figure 3 reveals that quite similar patterns dominate women's apparel trade. According to Figure 3, the top five exporters by dollar volume accounted for almost 51 percent of the global women's apparel market share in 2003, and 64\% in 2017 .. Individually, China increased its global market share to a staggering 45 percent over the 25-year period, but had some noticeable fluctuations as well. Hong Kong again experienced a downward trend, ending the period with less than four percent of the world total market share. All others roughly stayed within a four to seven percent corridor of the world total market 


\section{Macrothink}

share during the entire 25-year period. Overall, the top five exporters reflect the same rank order for market share for women's apparel trade as for the total apparel trade. ${ }^{1}$

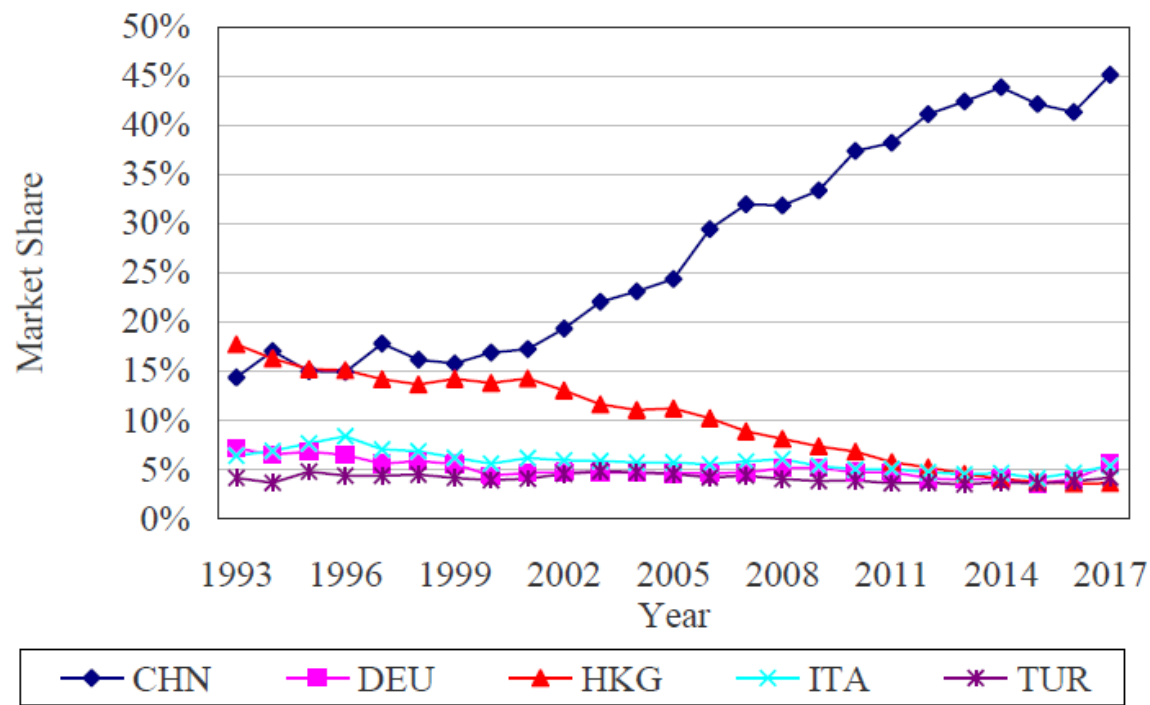

Figure 3. Market Share for the Top Five Exporters in Global Women's Apparel Trade (SITC III 842+844): 1993-2017

Data Source: UN Statistics Database

Figure 4 shows the results of Vollrath's Relative Trade Advantage (RTA) Index for the top five exporters in global women's apparel trade for the years 1993 to 2017. To our surprise, RTA patterns in women's apparel almost exactly matched the patterns of overall apparel, with only slightly slower decreases in RTA for Turkey and China in women's apparel as compared to apparel overall. China, and Turkey experienced strong declines but maintained comparative advantage, Hong Kong and Italy, starting from lower RTA levels, experienced mild declines, but ended up with neither an advantage or disadvantage. Germany, however, as mentioned previously, experienced an upward trend that indicated a slight decrease in its disadvantage in global women's apparel trade. During this period, Turkey and China's RTA values were predominantly higher and more volatile than the other top exporters, while Turkey demonstrated the highest RTA values of the five throughout the entire time period.

\footnotetext{
${ }^{1}$ Similarly to apparel overall, only Spain and India (not shown in figure 3), both with roughly four and a half percent market share, were able to break into the top five group.
} 


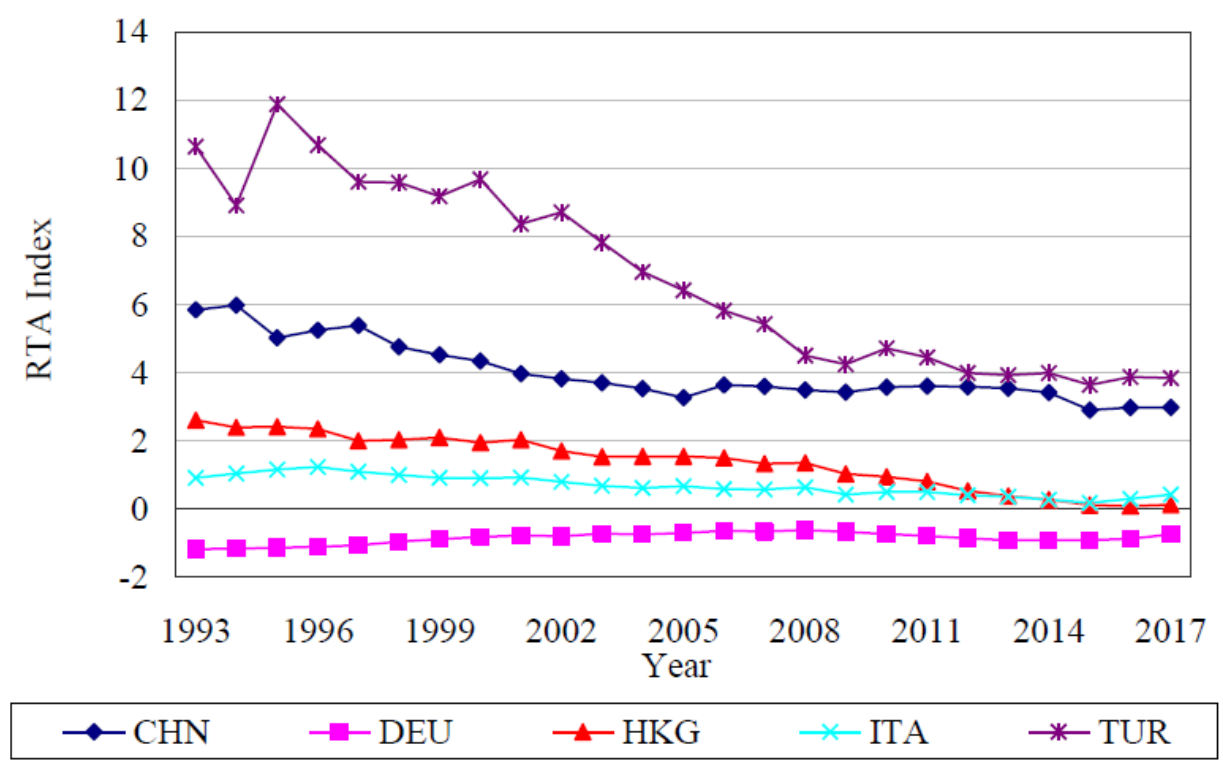

Figure 4. Vollrath's RTA Index Results for the Top Five Exporters in Global Women's Apparel Trade (SITC III 842+844): 1993-2017

Data Base: UN Statistics Database

6.3 Rank Order of Top Exporters by Market Share and RTA: 20 Subcategories of Women's Apparel

Figures 5 and 6 present the rank order by export market share and the RTA values of the top five exporters in the apparel total category, women's total apparel category, and twenty selected subcategories of women's apparel for the year 2003, respectively. As can be seen in Figure 5, these five exporters are still the largest dollar volume players at the disaggregate level. The exceptions are: subcategory 84331 (wool dresses) with India being the number one exporter in 2003; subcategory 84332 (cotton dresses) with India again being the number one exporter in 2003; subcategory 84351 (cotton blouses) with India again the number one exporter in 2003; and 84521 (knitted wool apparel) with Bangladesh the number one exporter in 2003. India's strong performance in the above three subcategories may well have paved its way into the top five exporters in women's apparel, but this is beyond the scope of the current study. Based on Figure 6, if making comparisons within each country among the subcategories, the results can also be used to identify the specialization areas that have been captured by each exporter. 


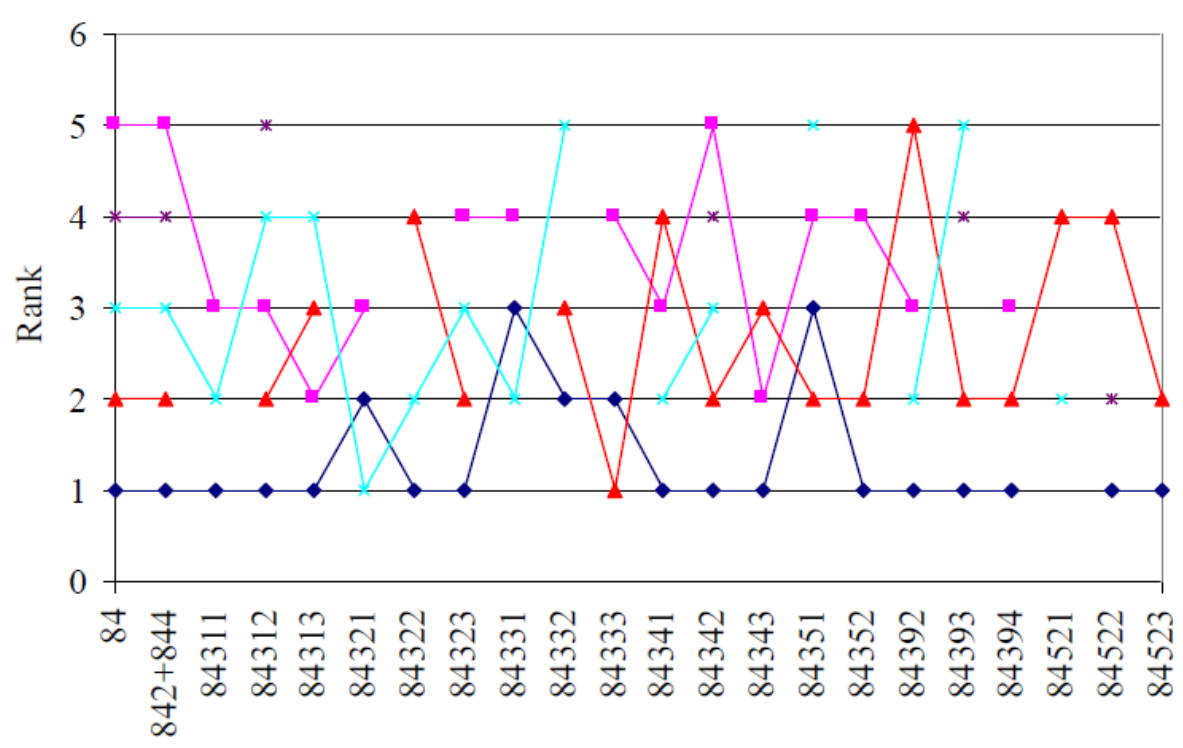

Category and Subcategories

$\rightarrow$ CHN $\rightarrow \mathrm{DEU} \rightarrow \mathrm{HKG} \quad \cdots$ ITA $\rightarrow$ TUR

Figure 5. Market Share Rankings for the Top Five Exporters in Apparel Trade in 2003

Note: If exporters fail to achieve top five market share ranking in a category or subcategory, this is expressed as a break or blank in the line for that category or subcategory for the exporter.

Category Explanations:

$84=$ total apparel $\quad 842+844=$ total women's apparel

84311, 84312, 84313 = women's coats and jackets, woven (wool, cotton, MMF)

$84321,84322,84323$ = women's suits and costumes, woven (wool, cotton, MMF)

84331, 84332, 84333 = women's dresses, woven (wool, cotton, MMF)

$84341,84342,84343$ = women's skirts, woven (wool, cotton, MMF)

84351,84352 = women's blouses, woven (cotton, MMF-no wool data)

84392, 84393, 84394 = women's other wovens (wool, cotton, MMF)

$84521,84522,84523$ = women's knitted garments (wool, cotton, MMF)

Data Source: UN Statistics Database 


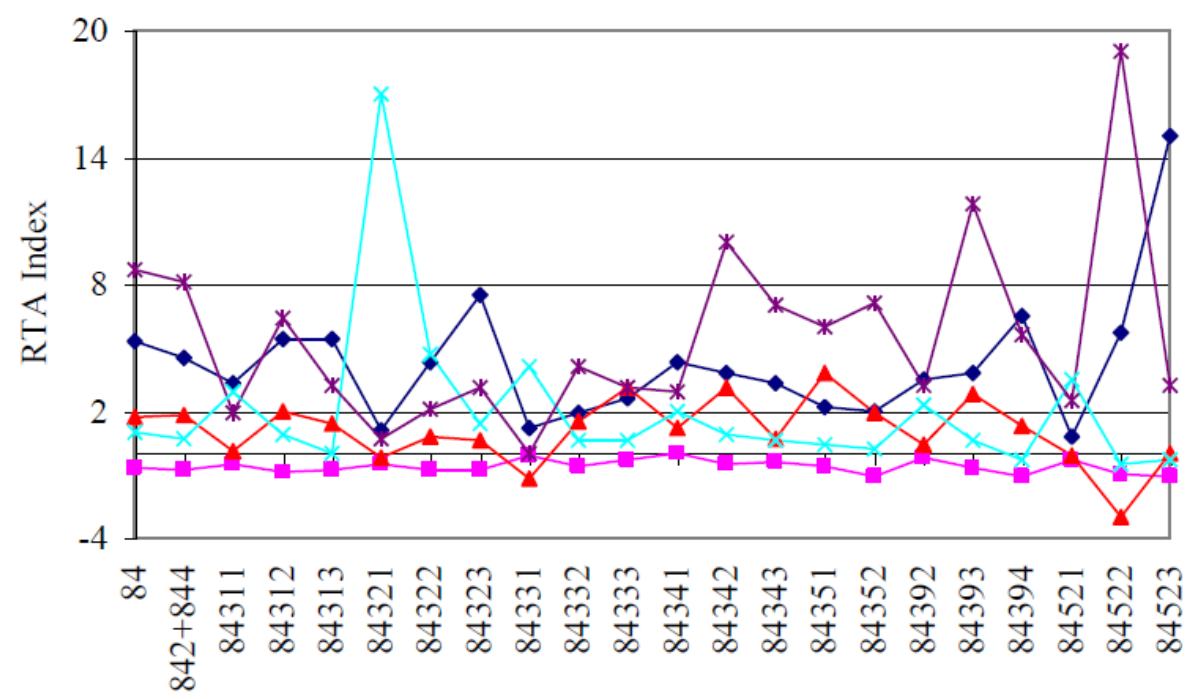

Category and Subcategories

$\rightarrow \mathrm{CHN} \rightarrow \mathrm{DEU} \rightarrow \mathrm{HKG} \rightarrow \mathrm{ITA} \quad$ - $\rightarrow$ TUR

Figure 6. Vollrath's RTA Index Results for the Top Five Exporters in Apparel Trade in 2003

Note: If exporters fail to achieve top 5 market share ranking in a category or subcategory, this is expressed as a break or blank in the line for that category or subcategory for the exporter.

Category Explanations:

$84=$ total apparel $\quad 842+844=$ total women's apparel

$84311,84312,84313$ = women's coats and jackets, woven (wool, cotton, MMF)

$84321,84322,84323$ = women's suits and costumes, woven (wool, cotton, MMF)

84331, 84332, 84333 = women's dresses, woven (wool, cotton, MMF)

$84341,84342,84343$ = women's skirts, woven (wool, cotton, MMF)

84351,84352 = women's blouses, woven (cotton, MMF-no wool data)

$84392,84393,84394=$ women's other wovens (wool, cotton, MMF)

$84521,84522,84523$ = women's knitted garments (wool, cotton, MMF)

Data Source: UN Statistics Database

\subsection{Summary of Results}

Among the top five exporters, the study results show that China has experienced the most consistent and strongest performance in terms of export market share rank at the disaggregate level. For example, China was number one in the majority of apparel trade subcategories and failed to rank first in only six out of 20 subcategories in our reference year, including women's wool suits and costumes, women's wool, cotton, or MMF dresses, women's cotton 
blouses, and women's knitted wool apparel. Of the six subcategories, only women's knitted wool apparel did not take China into the top five ranking. As would be anticipated, China exhibited relatively low RTA Index values in these subcategories, indicating areas in which China is in a less competitive position in the women's apparel trade.

Germany, which ranked number five for apparel total in 2003, did not rank in the "Big Five" in six out of the twenty subcategories, including women's cotton suits and costumes, women's cotton dresses, women's other woven garments of cotton, and women's knitted apparel of wool, cotton, or MMF. Germany's strength as an apparel exporter does not appear to lie in the cotton apparel product group or knitted apparel product group. Germany's negative values in all subcategories for the RTA Index indicate that imports have weighed more heavily than exports during the time period considered. Additionally, the apparel import/export picture in Germany has included the exportation of high-ticket apparel items and the importation of lower-ticket apparel goods. This does not contradict the fact that Germany has been an important exporter at the aggregate level and in some subcategories at the disaggregate level.

Hong Kong, the number two exporter for total apparel in 2003, joined the "Big Five" in all but three of the twenty subcategories, including women's wool coats and jackets, women's wool suits and costumes, and women's wool dresses. Hong Kong's strong trade area appears not to include the wool apparel product group, as confirmed by the RTA Index results. Also, for the above three subcategories, Hong Kong had negative RTA Index values, meaning the import side weighed more heavily than the export side. The only exception to this is in women's knitted cotton apparel, where Hong Kong had a negative RTA index while still ranking as the number four exporter in this category. This result may reflect apparel goods that are re-exported from China (Feenstra \& Hanson, 2004).

Italy, the number three exporter for apparel total in 2003, did not rank in the "Big Five" in six out of the twenty subcategories, including women's MMF dresses, women's MMF skirts, women's MMF blouses, women's other woven MMF apparel, women's knitted cotton apparel, and women's knitted MMF apparel. It is clear that Italy does not have as strong an exporting performance in the MMF apparel product group as it demonstrates in other apparel product groups, as confirmed by Italy's low values in the RTA Index results.

Turkey, the number four exporter for apparel total in 2003, showed a totally different picture from the other four exporters, entering the "Big Five" rank in only four out of the twenty subcategories. These subcategories include women's cotton coats and jackets, women's cotton skirts, women's other woven cotton apparel, and women's knitted cotton apparel. Noticeably, Turkey is strong in exporting a variety of cotton apparel products. Also, Turkey had higher RTA Index values for these four subcategories than for the other sixteen subcategories.

\section{Conclusion}

The apparel trade enjoys a unique status as one of the first industries to go global — from its role at the beginning of the Industrial Revolution to its role in the economies of developing 
countries today. In 2003 the dollar volume for apparel exports worldwide reached \$211 billion, with more than one-third of that total in women's apparel. By 2017, it had almost doubled to \$ 394 billion, with the share in women's apparel slipping down to just below one third. Women's apparel is important because: (1) it is the largest single sector of apparel exports, an area having huge economic import; (2) increased emphasis on fashion is driving up the demand for women's apparel as economies and markets around the world develop and mature; and (3) recent changes in trade policy have put apparel trade in the public eye. This suggests that understanding the comparative advantage of women's apparel exporters should be of growing importance to countries, industries, and individual businesses, given that everyone faces much steeper competition and must work even harder to build or maintain successful apparel trade using their unique industrial, environmental, and national conditions (Kaplinsky, 2000; Jin, 2004; Tokatli \& Kizilgun, 2004). However, understanding the nature of comparative advantage in trade has proven to be complex, and little insight into comparative advantage has been provided by research to date in the apparel trade area.

To address the lack of research on comparative advantage for the apparel industry, specifically the women's apparel sector, this study investigated total exports as well as selected export subcategories of women's apparel for the top five exporters of women's apparel in the world, China, Hong Kong, Italy, Turkey, and Germany between 1993 and 2017. In order to answer the question of comparative advantage in the women's apparel trade, Vollrath's (1987) RTA Index, an index that has received insufficient attention in the international trade literature, especially in apparel trade research, was calculated using data from the UN Statistics Database (1993-2017). Given that analysis at the aggregate level of apparel trade can identify the overall performance of a country in that industry, while analysis at the disaggregate level, i.e., apparel subcategories, can be used to evaluate specialization patterns along narrow product lines, both aggregate and disaggregate data analyses were conducted for this study.

Results indicate that for apparel total and women's apparel total, except for Germany, the remaining four top exporters had a comparative advantage and exhibited a trend to maintain it between 1994 and 2003. Even with MFA restrictions in place, these exporters maintained the trend for the period of study, suggesting a continuation for the years following the MFA phase-out, safeguards on China not withstanding. After the ATC was abandoned, China started to dominate apparel trade, notwithstanding the fact that its comparative advantage decreased. By the end of 2017, only China and Turkey were able to maintain their comparative advantage in both women's apparel and apparel overall. Italy and Hong Kong lost their comparative advantage by then. At disaggregate levels, results indicate that among the top five women's apparel exporters China has experienced the most consistent performance, specializing along narrow product lines in the women's apparel sector, likely paving the way for its take-off after the ATC was abandoned. Germany, on the contrary, has not specialized among the subcategories, although it has still maintained its position as a large exporter of women's apparel in general. Hong Kong has specialized in the cotton and MMF apparel product groups, Italy in the wool and cotton apparel groups, and Turkey in the cotton apparel group. It should be noted that results of this study suggest that although the 
comparative advantage revealed at the aggregate level (total apparel and total women's apparel exports) sets a baseline for each exporter's performance, it cannot be assumed that the results from the aggregate data hold true at the disaggregate level. As shown previously, this is not always the case.

In discussing the implications of the study results, several concerns should be noted and kept in mind. The data used in this study are secondary data, and, in relationship to apparel exports and women's apparel exports, the categorization of export goods used by the United Nations allows only certain comparisons. In particular, women's apparel exports can only be investigated within the woven and knitted categories because of the aggregation of men's, women's, and children's exports in other apparel classifications. This, in consequence, impacts the inclusiveness of approximations for the total and category estimates. Furthermore, within the women's categories, for example, women's cotton skirts, the dataset classification provides no way to distinguish between price, quality, style, or other characteristics of the products within the category.

\section{Discussion}

As mentioned above and shown in Table 1, China held and still holds the position of number one exporter in total apparel and women's apparel, with strong performance at the aggregate level and within almost all the subcategories of women's apparel exports. This position has been due primarily to the resource advantage of low cost labor. It is speculated that as China's national economy develops and its wage rate increases, the future of its apparel industry should be supported by an increasingly skilled labor force and brand building efforts. Further economic development will likely also entail more capital-intensive initiatives. Among the six subcategories where China did not rank as the largest exporter, five of them are categories with less than 2 billion dollars in trade volume in 2003 and do not represent a significant proportion of total apparel trade. Considering China's strong performance in the remaining 14 subcategories, it might be assumed that this specialization pattern has been due to China's strategic planning and its intentional targeting of large volume export areas. Additionally, the domestic market in China is itself a substantial one to serve. Unless there is a major shift in global demand for those subcategories, it appears unlikely that China will target those particular trade niches in the future. The subcategory of women's cotton woven blouses is the only subcategory with a significant trade volume (greater than 2 billion dollars in 2003) in which China did not rank number one. The story here is competition and comparative advantage in other countries. Number one in this subcategory is India. Logic suggests that increased competition between China and India in this area will continue.

For Germany, the RTA Index values did not show any specialization area among the subcategories based on the data analysis in this study. However, Germany shows strong performance in designer fashion and brand products, i.e., strong performance in high-end goods (Adler, 2004). This has maintained Germany as a large exporter in terms of dollar volume. However, as new players with trade advantage enter the global market, Germany will be facing more competition in narrow product lines, which may finally threaten its position as one of the largest exporters for apparel total. 
Hong Kong, due to its proximity to Mainland China, has used its advantage of being a marketing, financial, and transportation center for China's export business, to remain the second largest apparel exporter in the world. Its specialization areas of women's apparel were in the cotton and MMF product groups. With Mainland China's stronger performance and more preferential access to the world market, Hong Kong lost its strong performance at both the aggregate and disaggregate level in women's apparel trade.

Table 1. Development Space for Other Exporters

\begin{tabular}{|c|c|c|c|}
\hline $\begin{array}{l}\text { SITC } \\
\text { Code }\end{array}$ & Description & $\begin{array}{l}\text { Top Five Exporters } \\
\text { Based on Market Share* }\end{array}$ & Trade Volume \\
\hline 84 & Total apparel & CHN, HKG, ITA, TUR, DEU & $211 \mathrm{~b}$. \\
\hline $842 / 844$ & Total women's apparel & CHN, HKG, ITA, TUR, DEU & $71.5 \mathrm{~b}$. \\
\hline 84311 & Women's coats and jackets, woven, wool & CHN, ITA, DEU, Romania, Spain & $1.5 \mathrm{~b}$. \\
\hline 84312 & Women's coats and jackets, woven, cotton & CHN, HKG, DEU, ITA, TUR & $2.0 \mathrm{~b}$. \\
\hline 84313 & Women's coats and jackets, woven, MMF & CHN, DEU, HKG, ITA, Romania & $2.5 \mathrm{~b}$. \\
\hline 84321 & Women's suits and costumes, woven, wool & ITA, CHN, DEU, Indonesia, France & $0.2 \mathrm{~b}$. \\
\hline 84322 & Women's suits and costumes, woven, cotton & CHN, ITA, India, HKG, Fiji & $0.6 \mathrm{~b}$. \\
\hline 84323 & Women's suits and costumes, woven, MMF & CHN, HKG, ITA, DEU, Thailand & $0.9 \mathrm{~b}$. \\
\hline 84331 & Women's dresses, woven, wool & India, ITA, CHN, DEU, France & $0.07 \mathrm{~b}$ \\
\hline 84332 & Women's dresses, woven, cotton & India, CHN, HKG, Indonesia, ITA & $0.8 \mathrm{~b}$. \\
\hline 84333 & Women's dresses, woven, MMF & HKG, CHN, India, DEU, Indonesia & $1.5 \mathrm{~b}$. \\
\hline 84341 & Women's skirts, woven, wool & CHN, ITA, DEU, HKG, Romania, & $0.3 \mathrm{~b}$ \\
\hline 84342 & Women's skirts, woven, cotton & CHN, HKG, ITA, TUR, DEU & $1.9 \mathrm{~b}$. \\
\hline 84343 & Women's skirts, woven, MMF & CHN, DEU, HKG, Romania, India & $1.3 \mathrm{~b}$. \\
\hline 84351 & Women's blouses, woven, cotton & India, HKG, CHN, DEU, ITA & $3.3 \mathrm{~b}$. \\
\hline 84352 & Women's blouses, woven, MMF & $\begin{array}{l}\text { CHN, HKG, Romania, } \\
\text { DEU, Indonesia }\end{array}$ & $2.4 \mathrm{~b}$ \\
\hline 84392 & Women's other woven apparel, wool & CHN, ITA, DEU, Tunisia, HKG & $0.8 \mathrm{~b}$ \\
\hline 84393 & Women's other woven apparel, cotton & CHN, HKG, Mexico, TUR, ITA & $14.8 \mathrm{~b}$ \\
\hline 84394 & Women's other woven apparel, MMF & CHN, HKG, DEU, France, Belgium & $8.1 \mathrm{~b}$. \\
\hline 84521 & Women's knitted apparel, wool & $\begin{array}{l}\text { Bangladesh, ITA, United Kingdom, } \\
\text { HKG, United States }\end{array}$ & $0.1 \mathrm{~b}$ \\
\hline 84522 & Women's knitted apparel, cotton & CHN, TUR, India, HKG, Australia, & $0.9 \mathrm{~b}$. \\
\hline 84523 & Women's knitted apparel, MMF & $\begin{array}{l}\text { CHN, HKG, Mexico, France, } \\
\text { South Korea }\end{array}$ & $1.4 \mathrm{~b}$ \\
\hline
\end{tabular}

Source: UN Statistics Database

Note: Market share is presented in order, $1^{\text {st }}$ to $5^{\text {th }}$ ranking, from left to right.

Italy, with its long history in fashion design and production, has fared well for the last decade as one of the largest apparel exporters. However, its lack of access to man-made fibers continues to constrain its ability to compete in this area, and it did not do well in MMF 
apparel product subcategories over the time period analyzed in this study. Its strength in exports has been in the wool and cotton product subcategories. Unless a new supply of MMF becomes available to Italy, it is unlikely that Italy will have much trade advantage in the MMF-related areas in the future.

Turkey, a newer global trade player than the other four trade entities examined here, has done especially well in the women's cotton apparel group, which is considered a less capital and technology-intensive group than the wool and MMF apparel subcategories. Turkey's performance in the cotton apparel subcategories can be seen as a good example and starting point for countries wanting to enter the global market. Given that Turkey had extremely high RTA values for the cotton subcategories and demonstrates a trend to maintain these high RTA values, it is likely that Turkey will continue its strong performance in those areas. However, because of the less capital intensive nature of these subcategories, competition on a world level will come from a number of developing countries, especially India, where a tradition in cotton fabric production and a large, cheap labor force would support development in these subcategories.

For the exporters that were not among the top five exporters of women's apparel, Table 1 identifies some of the development spaces that might be considered for future women's apparel trade. The subcategories with a trade volume larger than 2 billion dollars in 2003 (one percent of the total apparel trade volume) in 2003 were women's other woven cotton apparel, women's other woven MMF apparel, women's woven cotton blouses, women's woven MMF coats and jackets, women's woven MMF blouses, and women's woven cotton coats and jackets, from high to low. Among them, the women's other woven cotton apparel and the women's woven MMF blouse subcategories offer enticing development space for smaller exporters because only three of the top five largest exporters were in the top five list for theses categories based on market share. Next, the women's other woven cotton apparel, the women's woven cotton blouse, and the women's woven MMF coats and jackets categories show four of the top five largest exporters competing in the top five list based on market share. In addition, women's other woven apparel using other fibers (which was not included in this study's data analysis) is one area with approximately 4 billion dollars in trade volume, making it another market development space for smaller exporters.

Besides the five top exporters of women's apparel that have been the focus of this study, there are other exporters, such as France, India, Indonesia, and Romania that are making it into the top five exporters for some of the women's apparel subcategories based on market share. These countries may benefit from the safeguards that have been placed on China after the January 1, 2005 MFA phase-out. A closer look at these smaller exporters may help identify a looming new order of global trade for apparel in the future.

France holds a position in apparel export that is similar to Germany. While France has enjoyed a trade advantage in neither apparel total nor the apparel subcategories, in some of the subcategories, such as women's woven suits and costumes in wool, women's woven dresses in wool, women's other woven apparel in MMF, and women's knitted apparel in MMF, France was still one of the largest exporters in the world. In the future, as new players 
with trade advantages enter world competition, France's position as a large exporter in some of the apparel subcategories will be at risk. Its position as a leader in fashion apparel and designer brands, however, will continue to work in France's favor in the global apparel market.

India has been described as Asia's second giant and will play an important role in apparel trade in the future (Engardio, 2005). Although India was not in the top 10 list for total apparel export in terms of dollar volume in 2003, it was among the top five in seven of the women's apparel subcategories, as shown in Table 1. The RTA Index values for India were around four in recent years for apparel total. At the same time, India experienced RTA values greater than 25 in women's woven dresses in wool, women's woven dresses in cotton, and women's woven blouses in cotton. The outstanding performance in these subcategories can be seen as the result of India's advantages in the apparel industry, such as competitive labor costs, abundant raw materials, local textile production, and skilled designers. According to USITC 2001, India was the world's third largest cotton producer with $25 \%$ of the world's cotton area under cultivation and 15\% of the world's cotton output (Padhi, Pauwels, and Taylor, 2004). Although India is expected to continue its focus on export in the technology and service industries, it will also seek to build its apparel exports (Engardio, 2005). India currently struggles with infrastructure issues, such as port capacity, logistics, and energy production, but as it addresses and moves to resolve some of these issues, it would be expected to see India continue strong performance in the specific subcategories of apparel export where it enjoys comparative advantage.

Indonesia has done well in the export of women's apparel with outstanding performance in women's woven suits and costumes in wool, women's woven dresses in cotton and MMF, and women's woven blouses in MMF, especially in 2003. Due to the Asian economic crisis at the end of 1997, Indonesia experienced a dip in its RTA values starting in 1998 (Hassler, 2004). After that, however, Indonesia has experienced a steadily increasing trend, and in 2003, the above-mentioned subcategories reached RTA values as high as 5. The government has been supportive and has provided opportunities to improve exporting efforts, for example, in some instances it has introduced duty exemptions and drawback facilities which have allowed exporters in Indonesia to source at international prices and operate their production facilities as if they were operating out of an Export Processing Zone (EPZ). This has positioned Indonesian apparel exporters to be more competitive in the global market (Hassler, 2004). These factors suggest that Indonesia will be able to maintain comparative advantage in these specific subcategories in the near future.

Romania has also been an active player at the disaggregate level in women's apparel exports, specifically in women's woven coats and jackets in wool, women's woven coats and jackets in MMF, women's woven skirts in wool, women's woven skirts in MMF, and women's woven blouses in MMF. The RTA values for apparel total were around 8 in recent years, and RTA values for these five subcategories were even higher, with the lowest being 14 . Romania's increasing intra-industry specialization with the EU, especially international production networks with Italy, and expanding processing in the apparel industry are important novelties of the last couple of years (Hunya, 2002). As a result, the trend of RTA 
values for each subcategory was either constant or upward, which means, for the near future, the same strong or even stronger performance can be expected in the same areas for Romania.

In considering a post-MFA world, this study has presented another look at comparative advantage for the top five women's apparel exporters between 1993 and 2017, using Vollrath's Index, an index little applied in the apparel area. It has also provided a look at possible future market development space using the RTA Index and market share performance of these top performing export countries and the countries challenging the world market within specific women's apparel niches. Furthermore, it has shown the importance of disaggregate data, i.e., women's apparel subcategories, in understanding exactly where comparative advantage lies. In so doing, it has demonstrated some part of the complexity of comparative advantage. For example, China is number one overall, but does not have comparative advantage in all subcategories of women's apparel exports. Romania is not in the top five exporters of women's apparel, but is a strong competitor within several of the women's apparel subcategories. Also, our data demonstrate that being a large exporter for certain products does not necessarily mean having comparative advantage in those areas. The cases of Germany and Hong Kong are examples of this. Germany, being the number five exporter in women's apparel overall in 2003 and among the top five in 14 out of 20 subcategories in the women's apparel trade, did not have a calculated comparative advantage for any of the above mentioned areas, which suggests a vulnerable position for this country, especially relative to lower price point goods. Hong Kong, as the number four exporter for women's cotton knitted apparel, did not show a comparative advantage in that area either, perhaps making its future in that category vulnerable.

It should be noted that the foundation of the theory of comparative advantage is that nations/firms with advantages in key resources in a given product area can and will compete more effectively than others. Traditionally, the key resources considered when assessing comparative advantage have been labor, land, and physical capital-resources that reflect a nineteenth century perspective. While these resources are still critical and will continue to be a factor in future market development, review of the exporters enjoying outstanding performance in women's apparel trade between 1993 and 2017 reveals a strong element of what might be called "new" resources. These resources include, among others, strategic planning at the industry level, government policy and programs, market access, and technology. For example, China, Indonesia, and Turkey all have benefited in their apparel industry performance from government policy and programs. In the case of Turkey, this has been despite rising wages for labor. It might be speculated that India, a looming competitor in women's apparel, may be able to leverage its expertise in computer and information technology to position its apparel industry for future success. The message here is that redefining the resources that support comparative advantage may be the key for future success in the apparel trade.

Overall, the results of the data analyses in this study suggest that the RTA Index can provide another important insight into the comparative advantage of exporters of women's apparel. The study results have indicated possible future market space development among giants and potentially up-and-coming apparel exporting nations. The RTA Index has proven to be a 
useful tool that adds to our understanding. As such, it helps to clarify in part the very complex topic of comparative advantage and deserves to be used more often for future studies of apparel exports. The complexity and the factors surrounding comparative advantage, as well as the limitations of the tools available to measure it suggest, however, that perhaps when future market space for women's apparel is considered the appropriate term should be apparent comparative advantage.

\section{Future Research Opportunities}

There are a number of interesting research opportunities suggested by this study and its results. The most obvious of these would be the importance to continue using Vollrath's Index and to extend this study to capture more details on comparative advantage. Future extensions might include: (1) a study of all apparel and related products; (2) a study of textiles and apparel together; and (3) a study that broadens the countries analyzed to include the top 20 global exporters, for example. Also, research efforts should be directed at continuing the improvement of the indices used to measure comparative advantage. Researchers would welcome the development of an alternative index that is more sensitive to fluctuations in textile and apparel trade and that does a better job of including scale effects. Also, all of the current indices used to measure comparative advantage are predicated on the assumption that ownership and production are located in the same country. It would be useful to have available a new index that takes into account the global shift in production location. Finally, given that Vollrath's and other similar indices are based on actual trade shipments between countries and not ideal shipments (shipments where no quotas are imposed), another study might be an exploration of comparative advantage that takes into account the effect of quotas on apparel exports to the United States and the EU.

\section{References}

Adler, U. (2004). Structural change: The dominant feature in the economic development of the German textile and clothing industries. Journal of Fashion Marketing and Management, 8(3), 300-319. https://doi.org/10.1108/13612020410547815

Arıcanl1, T., \& Rodrik, D. (Eds.) (1990). The Political Economy of Turkey: Debt, Adjustment, and Sustainability. St Martin's Press, New York, NY.

https://doi.org/10.1007/978-1-349-11274-6

Balance, R. H., Forstner, H., \& Murray, T. (1987). Consistency tests of alternative measures of comparative advantage. Review of Economics and Statistics, 69, 157-161.

https://doi.org/10.2307/1937915

Balassa, B. (1965). Trade liberalization and "Revealed" Comparative Advantage. Manchester School, 33(2), 99-123. https://doi.org/10.1111/j.1467-9957.1965.tb00050.x

Chen, C., \& Shih, H. (2004). The impact of WTO accession on the Chinese garment industry. Journal of Fashion Marketing and Management, 8(2), 221-229.

https://doi.org/10.1108/13612020410537906

Chun, L. (2003). What is China's comparative advantage? The Chinese Economy, 36(2), 3-20. 
https://doi.org/10.1080/10971475.2003.11033463

Deardorff, A. V. (1979). Weak links in the chain of comparative advantage. Journal of International Economics, 9(2), 197-210. http://dx.doi.org/10.1016/0022-1996(79)90003-5

Doryan, E. A. (1993). An institutional perspective of competitiveness and industrial restructuring policies in developing countries. Journal of Economic Issues, 27(2), 451-459.

https://doi.org/10.1080/00213624.1993.11505428

Engardio, P. (2005). A new world economy. Business Week.

https://doi.org/10.1109/EMR.2005.27009

Feenstra, R. C., Hai, W., Woo, W. T., \& Yao, S. (1999). Discrepancies in international data: an application to China-Hong Kong entrepôt trade. American Economic Review Papers and Proceedings, 89, 338-343. https://doi.org/10.1257/aer.89.2.338

French, S. (2017). Revealed comparative advantage: What is it good for? Journal of International Economics, 106, 83-103. https://doi.org/10.1016/j.jinteco.2017.02.002

Gereffi, G. (1999). International trade and industrial upgrading in the apparel commodity chain. Journal of International Economics, 48, 37-70.

https://doi.org/10.1016/S0022-1996(98)00075-0

Guercini, S. (2004). International competitive change and strategic behavior of Italian textile-apparel firms. Journal of Fashion Marketing and Management, 8(3), 320-339.

https://doi.org/10.1108/13612020410547824

Hassler, M. (2004). Changes in the Indonesian clothing industry: trade and regulation. Singapore Journal of Tropical Geography, 25(1), 64-76.

https://doi.org/10.1111/j.0129-7619.2004.00173.x

Hathcote, J., \& Nam, J. (1999). Advantages of sourcing apparel from China, Taiwan, South Korea, and Mexico. International Trade Journal, 13(2), 157-186.

https://doi.org/10.1080/088539099272008

Havrila, I., \& Gunawardana, P. (2003). Analyzing comparative advantage and competitiveness: An application to Australia's textile and clothing industries. Australian Economic Papers, 42(1), 103-118. https://doi.org/10.1111/1467-8454.00189

Hunya, G. (2002). Restructuring through FDI in Romanian manufacturing. Economic Systems, 26, 387-394. https://doi.org/10.1016/S0939-3625(02)00063-8

Jin, B. (2004). Apparel industry in East Asian newly industrialized countries: Competitive advantage, challenge and implications. Journal of Fashion Marketing and Management, 8(2), 230-244. https://doi.org/10.1108/13612020410537915

Jones, R. M. (2003). The women's wear industry in the U.K in 1993-2001: a statistical review. Journal of Fashion Marketing and Management, 7(2), 207-224.

https://doi.org/10.1108/13612020310497001 
Kaplinsky, R. (2000). Globalisation and unequalisation: what can be learned from the value chain analysis? Journal of Development Studies, 37(2), 117-147.

https://doi.org/10.1080/713600071

Peter, K., \& Ting, C. (2006a). Longitudinal patterns of comparative advantage in the textile complex - part 1: An aggregate perspective. Journal of Fashion Marketing and Management: An International Journal, 10(2), 134-149.

https://doi.org/10.1108/13612020610667469

Peter, K., \& Ting, C. (2006b). Longitudinal patterns of comparative advantage in the textile complex - part 2: Sectoral perspectives. Journal of Fashion Marketing and Management: An International Journal, 10(2), 150-168.

https://doi.org/10.1108/13612020610667478

Kiray, M. (1990). The family of the migrant worker. In F. Ozbay (Ed.), Women, Family and Social Change in Turkey (pp. 72-79). Bangkok: UNESCO.

Kirchbach, F. V. (2003). A Country's Competitive Advantage. International Trade Forum. 1. [Online] Available: http://www.tradeforum.org/A-Countrys-Competitive-Advantage

Maneschi, A. (1998). Comparative Advantage in International Trade: A Historical Perspective. Cheltenham, U.K.: Edward Elgar.

Mardas, D., \& Moutos, T. (2002). The EU-Turkey Customs Union and Greece: Who is the loser?. International Advances in Economic Research, 8(4), 275-288.

https://doi.org/10.1007/BF02295502

Neidik, B. (2004). Organizational foundations of export performance: The case of the Turkish apparel industry. Journal of Fashion Marketing and Management, 8(3), 279-299.

https://doi.org/10.1108/13612020410547806

Ozcelik, E., \& Taymaz, E. (2004). Does innovativeness matter for international competitiveness in developing countries? The case of Turkish manufacturing industries. Research Policy, 33, 409-424. https://doi.org/10.1016/j.respol.2003.09.011

Padhi, A., Pauwels, G., \& Taylor, C. (2004). Freeing India's textile industry. McKinsey Quarterly. 00475394.

Porter, M. E. (Ed.) (1990). The Competitive Advantage of Nations. Macmillan, London. https://doi.org/10.1007/978-1-349-11336-1

Ricardo, D. (1817). Principles of Political Economy and Taxation, London, Murray.

Rosen, E. (2003). Making Sweatshops. University of California Press, Berkeley, CA.

Smith, A. (1977) The Wealth of Nations. Harmondsworth, England: Penguin Books.

Sonobe, T., Hu, D., \& Otsuka, K. (2002). The process of cluster formation in China: a case study of a garment town. Journal of Development Studies, 39(1), 118-139.

https://doi.org/10.1080/00220380412331322691 


\section{Macrothink}

Business and Economic Research ISSN 2162-4860 2020, Vol. 10, No. 2

Taplin, I. M., \& Winterton, J. (2004). The European clothing industry: Meeting the competitive challenge. Journal of Fashion Marketing and Management, 8(3), 256-261. https://doi.org/10.1108/13612020410547789

Taylor, G. (2004). China textile trade. Journal of Fashion Marketing and Management, 8(2), 136-140. https://doi.org/10.1108/13612020410537834

Tefertiller, K., \& Ward, R. (1995). Revealed Comparative Production Advantage: implications for competitiveness in Florida's vegetable industry. Agribusiness: An International Journal, 11(2), 105-116.

https://doi.org/10.1002/1520-6297(199503/04)11:2<105::AID-AGR2720110203>3.0.CO;2-G

Thompson, E. R. (2002). Clustering of foreign direct investment and enhanced technology transfer: evidence from Hong Kong garment firms in China. World Development, 30(5), 873-889. https://doi.org/10.1016/S0305-750X(02)00009-8

Tokatli, N., \& Kizilgun, O. (2004). Upgrading in the global clothing industry: Mavi Jeans and the transformation of a Turkish firm from full-package to brand-name manufacturing and retailing. Economic Geography, 80(3), 221-241.

https://doi.org/10.1111/j.1944-8287.2004.tb00233.x

Turkey: Heady growth will ease. (November 2004, No. 245). OECD Observer, p. 27.

United Nations Statistics Division. (2005). UN Commodity Trade Statistics Database (UN Comtrade). [Online] Available:http://www.un.org

Vollrath, T. L. (1987). Revealed Competitive Advantage for wheat. Economic Research Service Staff Report NO. AGES861030. United States Department of Agriculture, Washington, D.C.

Vollrath, T. L. (1991). A theoretical evaluation of alternative trade intensity measures of Revealed Comparative Advantage. Weltwirtschaftliches Archiv, 130, 265-279.

https://doi.org/10.1007/BF02707986

Walkenhorst, P. (2003). Liberalizing trade in textile and clothing: A survey of quantitative studies. Working Party of the Trade Committee. Paris: OECD, 2003/2.

https://doi.org/10.1787/eco_studies-v2003-art6-en

Webster, A. (1990). Comparative Advantage: assessing appropriate measurement techniques. Bulletin of Economic Research, 42(4), 299-310.

https://doi.org/10.1111/j.1467-8586.1990.tb00480.x

Yang, Y. (1999). China's Textile and Clothing Exports: Changing International Comparative Advantage and its Policy Implications. Asia Pacific School of Economics and Management, Working Paper No. CEP99-3. [Online] Available:

https://openresearch-repository.anu.edu.au/bitstream/1885/40361/3/cep99-3.pdf 


\section{Copyright Disclaimer}

Copyright for this article is retained by the author(s), with first publication rights granted to the journal.

This is an open-access article distributed under the terms and conditions of the Creative Commons Attribution license (http://creativecommons.org/licenses/by/4.0/). 